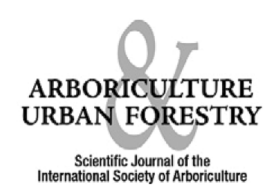

\title{
Urban Tree Growth Modeling
}

\author{
E. Gregory McPherson and Paula J. Peper
}

\begin{abstract}
Selecting, locating, and managing trees to provide ecosystem services are becoming increasingly important facets of municipal and consulting forestry. The science of urban tree growth modeling is fundamental to quantifying these services. This paper describes three long-term tree growth studies conducted to evaluate tree performance because repeated measurements of the same trees produce critical data for growth model calibration and validation. Several empirical and process-based approaches to modeling tree growth are reviewed. Modeling is more advanced in the fields of forestry and pomology than in urban forestry. The USDA Forest Service's reference city research has developed over 1,800 growth equations from measurements on more than 17,000 trees in 16 cities. The database is a valuable source of information that reflects regional differences in species composition, climate, soils, site conditions, and management practices. Several examples illustrate how differences in local climate and management practices can influence growth of a single species and the resulting value of services. Further advances in urban tree growth modeling are needed to inform the design, management, and modeling of high performing landscapes.

Key Words: Allometry; Ecosystem Services; Predictive Equations; Tree Growth; Urban Forest.
\end{abstract}

Selecting, locating, and managing trees to produce ecosystem services are becoming increasingly important facets of municipal and consulting forestry (Young 2010). This trend is driven from the top down and the bottom up. An increasing number of "green consumers" are demanding more from their landscapes than aesthetic appeal. At the same time, more policies, rules, and regulations are promoting green infrastructure, including trees and the soil that supports them (Benedict and McMahon 2006; Tzoulas et al. 2007). The potential to stack and sell the services trees produce is motivating arborists to begin thinking of trees as a solar-powered biotechnology, wherein their appearance is only one facet of overall value.

The science informing the design, selection, and management of high performing trees is relatively limited. Few long-term tree growth studies have been conducted. Although arboriculture literature is rife with studies that focus on effects of tree growth regulators (Sachs et al. 1986; Burch et al. 1996) and a variety of individual environmental stressors on growth (Goodfellow et al. 1987; Clark and Kjelgren 1990; Grabosky and Gilman 2004; Nielson et. al 2007), the relative effects of multiple stressors remains largely unknown. Much of the research has been carried out on young trees in controlled settings that are very different from the heterogeneous conditions found in cities (Sjöman and Nielsen 2010). The paucity of literature on tree growth science is rivaled by the dearth of urban tree growth modeling studies. Compared to the breadth and depth of growth modeling in the fields of forestry and pomology, urban tree modeling is in its infancy.

The purpose of this paper is to describe the current state of arboricultural knowledge concerning tree growth modeling. To begin several long-term tree performance studies are described because repeated measurements of the same trees produce critical data for growth model calibration and valida- tion. Two theoretical approaches to modeling tree growth are described, and their application in arboriculture and urban forestry are presented. The analytical potential of the USDA Forest Service's reference city database, which contains measurements of more than 17,000 urban trees, is rendered with several examples. Researchers conclude by advocating for greater interdisciplinary collaboration to advance tree growth modeling and renewed investment in long-term performance monitoring.

\section{TREE PERFORMANCE EVALUATION}

Long-term performance evaluation of tree species and cultivars is fundamental to tree growth modeling. Repeated measurements of tree size and health provide realworld data for modeling tree growth. Thorough descriptions of site conditions and management activities can be used with multivariate statistics to explain their influence on growth and performance. For centuries, foresters have been measuring the effects of site factors and management interventions on stand dynamics. The Forest Inventory and Analysis program has been monitoring U.S. forests since 1928 (Smith 2002). Recently, Forest Inventory and Analysis plots have been located in some urban areas. However, long-term studies of urban tree growth first began in the U.S. a half-century ago by arboreta, universities, and foundations. In the mid-1960s, Dr. L.C. Chadwick of Ohio State University and Mr. Bif Stapes of the Davey Tree Expert Company began evaluating street tree species in five Ohio cities, as well as trees planted in research plots. Now called the Street Tree Evaluation Project, the study expanded to include 89 revisited sites and continues to supply valuable "then and now" information on survival and growth, as well as photographic records of visual impacts as trees mature (Sydnor et al. 1999). 
In 1987, Dr. Henry Gerhold of Pennsylvania State University partnered with several electric utilities to begin the Municipal Tree Restoration Program. Test trees were planted in plots along streets and under electric conductors to compare performance in 11 Pennsylvania communities (Gerhold 2007). Twelve years of standardized performance data are helping utilities to select the most appropriate cultivars, and the plantings serve as living demonstrations. The primary tree performance metric for this program was tree height because utilities wanted trees that did not exceed $8 \mathrm{~m}$ height to plant under conductors.

In 2005, the National Elm Trial began producing standardized information on the performance of 20 Dutch elm disease (Ceratocystis ulmi) resistant cultivars in 18 plots across the country. Reports from this research include information on survival and growth, as well as damage from pests, disease, abiotic disorders, and pruning requirements (McPherson et al. 2009). High-performing cultivars require minimal treatment for pest infestations or pruning to develop strong structure.

\section{MODELING TREE GROWTH}

Forecasting urban tree growth is challenging because of the long time scales, transient dynamics of tree sites, multitude of management options and large number of tree species to model (Reineking et al. 2004). Estimates of tree size underpin modeling of ecosystem services. Accurate estimates of leaf surface area are particularly important because of its role mediating atmospheric fluxes like air pollutant and rainfall interception, photosynthesis, evapotranspiration, respiration, and shading. Two general approaches have evolved to model tree growth. First, empirical models predict tree dimensions, such as diameter at breast height (DBH) and crown volume based on measurements and statistical relationships found to exist among measured variables. Empirical models focus on tree morphology. Second, process-based models focus on tree physiology by translating rates of assimilation and allocation of carbon and other constituents into growth rates of tree diameters, heights, and other attributes. Examples of each modeling approach are discussed in the next section.

\section{Empirical Models}

Empirical models use field measurements of tree dimensions and statistical methods to predict diameter, height, and crown spread. When information on site conditions is included, separate models can be developed for the same species. There are hundreds of empirical models of forest growth, and the variety of models is both a strength and weakness. Empirical growth models can be very accurate for specific sites where extensive measurements were made, but the absence of grounding in a robust theory limits their application to other regions (Valentine and Mäkelä 2005). The advantages of empirical models are that they are quick to develop, require few inputs, and uncertainty can be quantified. Because empirical models do not explicitly incorporate causal dynamics, it is difficult to extrapolate how different management interventions will influence future growth. Empirical approaches are used to model urban tree growth in both i-Tree and Lindenmayer-Systems.

\section{i-Tree}

i-Tree is public domain software developed by the USDA Forest Service and cooperators for urban forestry analysis and benefits assessment. Within i-Tree, entire urban forests are assessed using Eco (formerly UFORE), and discrete street tree populations are assessed using Streets (formerly STRATUM). i-Tree quantifies urban forest structure, environmental effects, and value to communities from field data and local hourly air pollution and meteorological data (Nowak et al. 2008).

Eco estimates standardized tree growth (DBH) based on the number of frost free days and adjusts this base value with tree condition and crown light exposure data (Nowak 1994; Nowak et al. 2008). For example, for Sacramento, California, frost free days are assumed to be 305 , the annual base DBH growth rate is $0.83 \mathrm{~cm}$, and it ranges from 0.8 to $1.0 \mathrm{~cm}$ across all DBH classes. The base tree growth rate comes from urban street tree (Fleming 1988; Frelich 1992; and Nowak 1994), park tree (DeVries 1987), and forest growth (Smith and Shifley 1984) estimates that were standardized to growth rates for Minnesota, U.S. Average height growth is calculated based on formulas from Fleming (1988) and the specific DBH growth factor used for the tree.

Eco's growth rates are adjusted based on tree condition: fair to excellent condition, multiplied by 1 (no adjustment), poor condition - 0.76, critical condition - 0.42 , dying - 0.15 , dead - 0 . Growth adjustment factors are based on percent crown dieback and the assumption that less than $25 \%$ crown dieback had a limited effect on DBH growth rates (Nowak et al. 2008). Crown light exposure provides information on the number of sides of the tree receiving sunlight and ranges from 0 (no full light) to 5 (full light from top and four sides). Leaf area and biomass of trees are calculated using regression equations derived from measurements of 54 open-grown park trees in Chicago, Illinois, U.S., representing five species, and 34 smaller trees of 12 species from Poland. If required shading coefficients are unavailable for individual species, genus or hardwood averages are used.

Unfortunately, leaf area estimates generated with these regression equations were found to have little correlation with actual leaf area harvested for 50 Platanus trees in California (Peper and McPherson 2003). In a comparison of predicted and measured growth rates $(\mathrm{DBH})$ for common species in Gainesville, Florida, Eco's growth rates were very different than measured ones (Lawrence et al. 2012).

Calculations of ecosystem services produced by i-Tree Streets are based on tree size data collected from a reference city within each of the 16 United States climate regions (Peper and McPherson in preparation). The reference cities used were selected because they had updated computer inventories of at least 20,000 trees, good historic information on planting dates for aging trees, and large, old trees present in the community.

Between 18 and 22 predominant species were selected for sampling from each reference city tree inventory. Typically, the predominant species represent over $65 \%$ of the municipality's urban forest. Up to 10 trees were randomly sampled and measured in each of up to nine DBH classes. As few as 30 trees may have been measured for smaller-growing species and as many as 70 for larger-growing species, with individuals present in every size class. Measurements included DBH (to nearest $0.1 \mathrm{~cm}$ ), tree height, height to crown base, crown height, and crown diameter (all measured to nearest $0.5 \mathrm{~m}$ ). Digital images were captured to estimate leaf area based on a method developed by the authors (McPherson et al. 2003). Tree age, or the number of years after planting, was determined differently depending on the data available from cities and city foresters, but generally from a combina- 
tion of city records, historic data and imagery, local tree groups, and coring and cross-dating tree rings. Equations to predict DBH from age, and tree height, crown height, crown diameter, and leaf area from DBH were developed using least-squares linear and non-linear regressions to determine best fit. Over 1,800 equations are currently used within i-Tree Streets to predict growth and estimate the benefits and costs associated with street tree populations, including those published for California's San Joaquin Valley and Southern Coastal regions (Peper et al. 2001a; Peper et al. 2001b).

Testing the applicability of i-Tree Streets outside of the United States, Soares and others (2011) compared growth of urban species and genera from Lisbon, Portugal, to growth models used in i-Tree Streets. Finding similar growth for U.S. species from Mediterranean climates and lacking age-based growth curves for most species in Lisbon, the authors used growth curves for U.S. species.

\section{Lindenmayer-Systems}

Lindenmayer-Systems (L-Systems) are a mathematically-based theory of biological development used to model tree growth. L-systems describes the complex growth of trees using production rules that govern branching and growth at successive time steps (Prusinkewicz and Lindenmayer 1990). Brasch and others (2007) created empirical tree growth models with L-Systems so that modeled crown dimensions conformed to measured dimensions. Their approach based global characteristics such as tree height, crown diameter, and shape on empirically derived growth equations for nine deciduous species in Modesto, CA, (Peper et al. 2001a). These species' specific global characteristics informed and constrained models of tree growth that were driven by L-Systems' local production rules (Rudnick et al. 2007). Using 20 time steps per year for 40 years, branch production rules were applied to all branch segments based on the biological response of each organ to competition for light and space. Computer visualizations produced relatively accurate and life-like growth for each species. This work is important because it was the first to combine urban tree growth equations with L-Systems and computer animation software. It created realistic visualizations of long-term tree growth in a matter of seconds.

\section{Other Empirical Models}

Stoffberg and others (2008) developed tree height and crown size equations for three street tree species in Tshwane, South Africa based upon the same analytical methods used for i-Tree Streets tree growth predictions. Similarly, Semenzato and others (2011) included the logarithmic regression model proposed by Peper and others (2001a) in developing growth predictions for five important Italian urban species.

\section{Process-Based and Hybrid Models}

These types of models explicitly describe how the uptake and assimilation of carbon and other resources (e.g., nutrients, light, water) translate into morphological growth. Processbased models need many parameters to characterize a species, but modeling of processes need not be parameterized for each species once they are adequately described. Process modeling can define key growth parameters to help identify traits to measure. An advantage of process-based models is their ability to model the effects of different doses of stressors, such as with climate change, to identify physiological response thresholds. Disadvantages of process-based models are their complexity, which put a high demand on computer resources and cause difficulty quantifying uncertainty in model predictions.

\section{L-PEACH}

The L-PEACH functional-structural model was developed to better understand the effects of management decisions on the development, growth, and fruit yield of peach trees (Allen et al. 2005). It treats the tree as a network of semi-autonomous components that interact with each other and the environment. An electrical circuit analogy is used to compute the flow of carbohydrates among components. The most recent enhancement added a xylem circuit to simulate water uptake over a season and the effect of different irrigation regimes on growth and yield (Da Silva et al. 2011). A comparison of model outputs and measured water use indicated that the model successfully coupled water transport with growth. L-PEACH's 3D visualization makes it an educational tool for growers and students. Future development will improve light and root system modeling.

\section{Hybrid Models}

Valentine and Mäkelä (2005) suggest broaching the complexities of process-based modeling in modeling forest stands by developing a process-based model fitted and applied in an empirical mode. Their carbon-based model of tree growth incorporates minimal levels of structure and function, and uses commonly inventoried state variables-tree height, crown height, and stem cross sectional area. This is a straightforward and efficient attempt to address the frustration confronting all growth modelers - the absence of a robust model that melds fundamental biological knowledge of tree growth with a functional balance approach to modeling. Forest modelers face the frustration of having multiple models for the same species growing in the same habitat. Valentine and Mäkelä's work attempts to resolve this issue. Their methods may be applicable in urban settings where biotic and abiotic stressors are necessary to explain differences in tree growth, longevity, and mortality.

\section{Other Approaches}

Efficient methods for collecting field data for modeling, monitoring, and evaluating growth influences remain problematic. Municipalities often cannot afford to conduct inventories or collect data beyond what is required for the basic management of their tree populations. In addition to presenting growth research, the following studies took different approaches in efforts to resolve the data collection issue. Jutras (2008) conducted a comprehensive study on the influence of multiple biotic and abiotic factors on the growth of seven street tree species in Montreal, Canada. Using artificial intelligence and multivariate statistics, he accomplished three objectives. First, he found a combination of 11 biotic descriptors that illustrate all tree physiological stages. Next, he applied contingency analysis to determine links between abiotic variables, including urban zone type, surficial deposits, solar irradiation level, street width, distance from tree to curb, and tree growth. Last, he sought to optimize tree inventory procedures using aerial Light Detection and Ranging (LIDAR) combined with other less field work intensive variables. Ultimately, the efficiently collected data and the 
analyses of biotic and abiotic factors were combined to "train" artificial neural networks to predict tree growth. The modeling method demonstrates robust predictive capability despite differences in morphological characteristics within study species.

In research that could be adapted to urban settings, Salas et al. (2010) studied the use of airborne laser scanning, LIDAR and geographically weighted regressions to model DBH from LIDAR-based variables. LIDAR measurements in conjunction with a linear mixed-effect model produced DBH estimates with a $4 \%$ error rate. Seidel and others (2011) have used terrestrial LIDAR, also called 3D laser scanning, to nondestructively monitor plant biomass and growth of juvenile trees, with good correlation between scan and destructive harvest data for predicting leaf area and aboveground biomass.

Additional studies conducted in the search for efficient tree growth measuring and monitoring include the development of Urban Crowns (Patterson et al. 2011), a software program developed by the USDA Forest Service Southern Research Station that provides estimates of crown and tree height, diameter, ratio, volume, transparency, and density using a digital photographs and basic field measurements.

\section{USDA FOREST SERVICE REFERENCE CITY RESEARCH}

The authors compiled a master database containing all field data collected in the 16 i-Tree Streets reference cities plus several additional cities where research was conducted (Peper and McPherson in preparation). This database consists of more than 17,000 trees representing 171 unique species in 16 U.S. climate regions. In addition to the tree size variables measured for each tree and listed previously, the tree records include location information, measured growing space, setback distance, and orientation from tree to nearest conditioned space, land use, planting site description, wire and sidewalk conflicts, tree shape, and condition. The objective was to establish an accessible international tree growth database that researchers can use for comparative analyses. Selected trees may be re-measured to study growth over time. Multivariate statistical analyses may be conducted to identify relationships between tree size, growth, and biotic and abiotic variables.

The analytical approaches applied to the reference city data evolved over the ten-year period that research was conducted. During the first study in 1998, the study authors attempted to adapt the sigmoid-shaped model used by Frelich (1992) for Minneapolis, Minnesota, trees, but found that a loglog model fit better. The loglog model is typically used to fit tree growth data collected in forest stands. As the cross-country data collection continued, it became evident that no single model would fit all growth variables for any one species, let alone all species. Eventually, depending upon the city and species, loglogs, simple polynomials tested at various weights, and exponential models were fitted.

Analysis tools providing researchers with more accurate and efficient methods for comparing and selecting the best models have increased in number and capability since 1998. Thus, all of the data were recently re-analyzed using SAS 9.3 programming to test seven types of growth predictions for each species in each of the 16 climate regions. The objective was to select the best models and produce predictive equations for tree height, crown height, crown diameter, and leaf area from measures of $\mathrm{DBH}$, as well as to predict $\mathrm{DBH}$ from age and crown diame- ter. Seven models were tested (linear, quadratic, cubic, loglog, exponential, two-segment linear, three-segment linear) at four weights (equal weighted, $\operatorname{sqrt}(x), 1 / x$, and $1 / x^{2}$, where $x=\mathrm{DBH}$ or age). For a city where data were collected on 18 species, this method resulted in the testing of 3,528 models (18 sp $\times 7$ parameters $\times 7$ models types $\times 4$ weights) to determine the best fit.

Models having the best fit were selected using secondorder Akaike Information Criterion) testing $\left(\mathrm{AIC}_{\mathrm{c}}\right.$ ) and the delta $\operatorname{AIC}_{C}\left(\Delta_{\mathrm{i}}\right)$ to rank all models relative to the best model. As a rule of thumb, a $\Delta$ less than two suggests substantial evidence for the model. The $\Delta_{\mathrm{i}}$ for all selected models was less than one. The limitation of AIC is that if only poor models are tested, $\mathrm{AIC}_{\mathrm{C}}$ selects the best of the poor. Therefore, the adjusted $\mathrm{R}^{2}$ and mean squared error were examined and reported for each model as well. This analysis produced nearly 2,600 regionally specific equations predicting various tree dimensions. These, along with the database, will be published and placed online in a spreadsheet format for free public access and download.

\section{Comparing Growth and Services Produced by the Same Species}

Tree growth equations developed through the reference city work have been foundational for many tools used to calculate ecosystem services, including i-Tree Streets (i-Tree Team 2011), the National Tree Benefit Calculator (Casey Trees and Davey 2011), and Urban Forest Map (2011). They also provide opportunity for comparison with growth equations developed by other scientists and for like species growing in different regions. Many of the i-Tree reference cities share several of the same predominant species. For example, sweetgum (Liquidambar styraciflua) and honeylocust (Gleditsia triacanthos) are among the top 20 species in 10 cities, silver maple (Acer saccharinum) and callery pear (Pyrus calleryana) in nine cities, and green ash (Fraxinus pennsylvanica) in eight cities. As shown by the following examples, the predictive equations developed for these species allow professionals to examine trends and assess possible reasons for growth differences. Additionally, the master database and predictive equations are producing the basic parameters required for improved tools such as the webbased Tree Carbon Calculator (USDA Forest Service 2008).

Studies conducted in Westminster, Colorado, and Cheyenne, Wyoming, both in the U.S. North Climate Region, allow comparison with growth models developed from data collected on predominant species in Fort Collins, Colorado (McPherson et al. 2003). The Westminster study permitted verification of Fort Collins growth models (predicting diameter at breast height from age) with an independent data set from a nearby city ( $81 \mathrm{~km}$ south of Fort Collins) having similar growing conditions (Wood 2010). The study reported growth for 16 years after initial planting for 10 of the species shared by both cities. With the exception of cottonwood (Populus sargentii) and Austrian/ponderosa pine (Pinus nigra/P. ponderosa) $(2.0$ and $0.5 \mathrm{~cm} \mathrm{DBH}$ smaller in Fort Collins), the remaining Fort Collins species were predicted to grow larger than Westminster's (Figure 1). The difference ranged from about $2 \mathrm{~cm} \mathrm{DBH}$ for blue spruce to $7 \mathrm{~cm} \mathrm{DBH}$ for silver maple over the 16-year period. While relatively small, the differences probably reflect varia- 


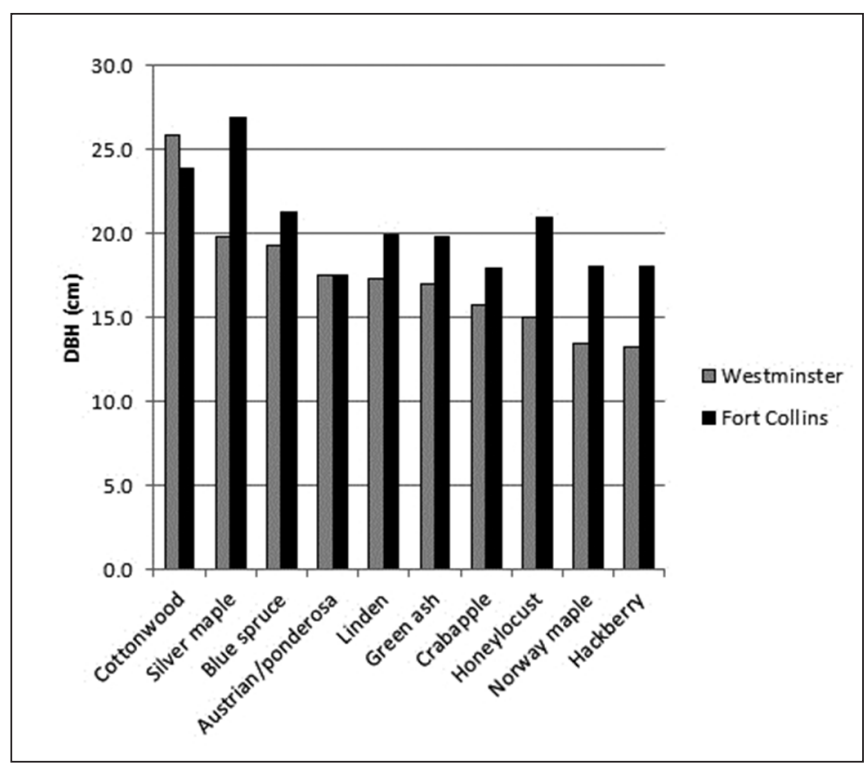

Figure 1. The comparison of predicted DBH size of Fort Collins trees with actual measurements of Westminster trees 16 years after planting indicates that mean tree growth over 16 years is generally greater in Fort Collins.

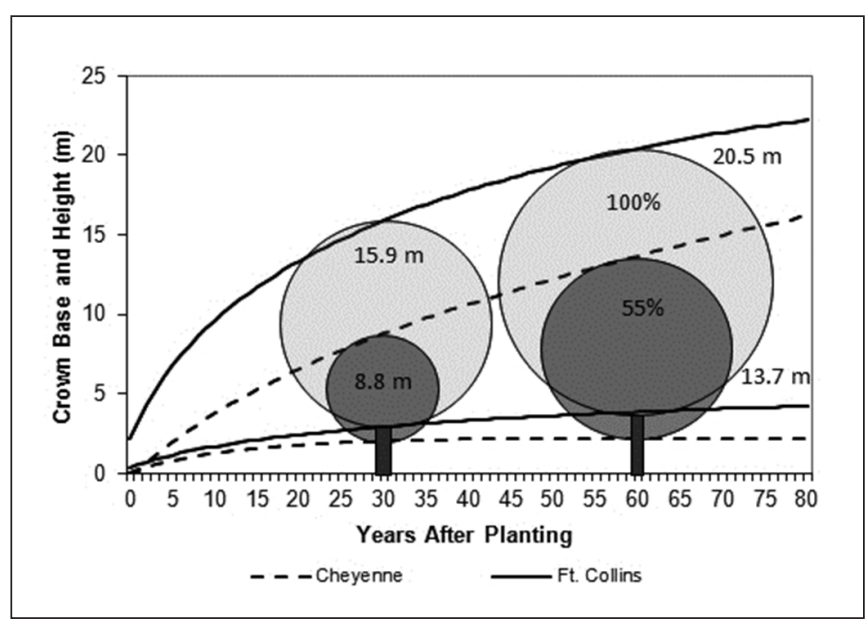

Figure 2. Tree height, crown base, and leaf area for same-aged green ash in Fort Collins and Cheyenne. Upper lines represent height. Lower lines represent height to first branch. Cheyenne ash have $55 \%$ of the Fort Collins' ash leaf area.

tion in management, growing space, location, climate, and soils. Fort Collins has slightly lower average monthly summer temperatures (up to $2^{\circ} \mathrm{C}$ lower) and up to 2.5 times the average late-summer precipitation than Westminster, which may boost growth. The similarities between the Fort Collins predictive models and the Westminster actual measurements suggest that model predictions are reasonable.

However, comparisons between Fort Collins and predictive models developed from data collected in Cheyenne, Wyoming, illustrate how differently the same tree species may grow within a single region. Cheyenne is $75 \mathrm{~km}$ north of Fort Collins and 156 $\mathrm{km}$ north of Westminster. Six species were measured in Cheyenne that also grew in Fort Collins. With the exception of the native Colorado blue spruce (Picea pungens), every species in Cheyenne was significantly smaller when compared to sameaged trees in Fort Collins. Beginning 30 years after planting, green ash (Fraxinus pennsylvanica) growing in Cheyenne consistently remain about $7 \mathrm{~m}$ shorter than the same species growing in Fort Collins (Figure 2). Crowns are pruned up about $1.5 \mathrm{~m}$ higher in Fort Collins than in Cheyenne, in relation to larger growth and proximity to roadways. Leaf area for the Cheyenne trees is estimated to be about 55\% of Fort Collins ash tree leaf area.

Because Cheyenne's municipal trees were generally healthy and well-managed (94\% in fair or better condition), the climatic and soil differences between the two cities were examined. At the time of the study, Cheyenne was listed as the fourth windiest city in the country with the highest incidence of hailstorms. At an elevation of $1860 \mathrm{~m}$, the city receives an average $366 \mathrm{~mm}$ of precipitation annually. The harsh climate and elevation combine with alkaline soils that have low water-holding capacity. These challenging growing conditions were a primary reason why the U.S. Congress established the USDA High Plains Horticultural Research Station in Cheyenne in 1928 (Torpey 2007). If trees, shrubs, and other plants could survive the conditions in Cheyenne, it was likely they would grow in other semiarid or dry land regions of the U.S. Fort Collins is lower in elevation (1525 $\mathrm{m})$ and receives only slightly more precipitation $(383 \mathrm{~mm})$, but generally has better soils than Cheyenne. Located adjacent to the Rocky Mountains rather than the open prairie, Fort Collins also receives more protection from the elements.

Differences in growth rates translate into significant differences in tree benefits (Table 1). At USD \$66,000 and \$201,000, respectively, the value of services produced by Cheyenne trees is about one-third of those produced by Fort Collins trees.

Growth models within and across different climate regions also present opportunities to examine tree management effects on growth and provisioning of services as demonstrated by a comparison of Siberian elms (Ulmus pumila) in Cheyenne and San Francisco, California. Trees were extensively pruned in San Francisco to limit conflicts with buildings, roads, and overhead wires (Figure 3). Although growing in a much milder climate than Cheyenne, the elms averaged only $9.8 \mathrm{~m}$ in height 40 years after planting, equal to the mature size of a small tree. Using the same pricing index for both cities, the value of ecosystem services provisioned by 100 elms over 40 years in San Francisco is $\$ 97,000$, or about $70 \%$ of those from the same species in Cheyenne (Figure 4).

Table 1. The total service values for 100 green ash trees (Fraxinus pennsylvanica) grown over $\mathbf{4 0}$ years in Fort Collins, Colorado, and Cheyenne, Wyoming. Benefit comparisons were calculated using the same pricing index for both cities. Currency is expressed in U.S. dollars.

\begin{tabular}{llllll}
\hline City & Energy & $\mathrm{CO}_{2}$ & $\begin{array}{l}\text { Air } \\
\text { quality }\end{array}$ & Stormwater & $\begin{array}{l}\text { Total } \\
\text { services }\end{array}$ \\
\hline Ft. Collins, CO & $\$ 85,845$ & $\$ 17,603$ & $\$ 14,476$ & $\$ 82,816$ & $\$ 200,740$ \\
Cheyenne, WY & $\$ 29,887$ & $\$ 5,623$ & $\$ 2,586$ & $\$ 27,660$ & $\$ 65,756$ \\
\hline
\end{tabular}



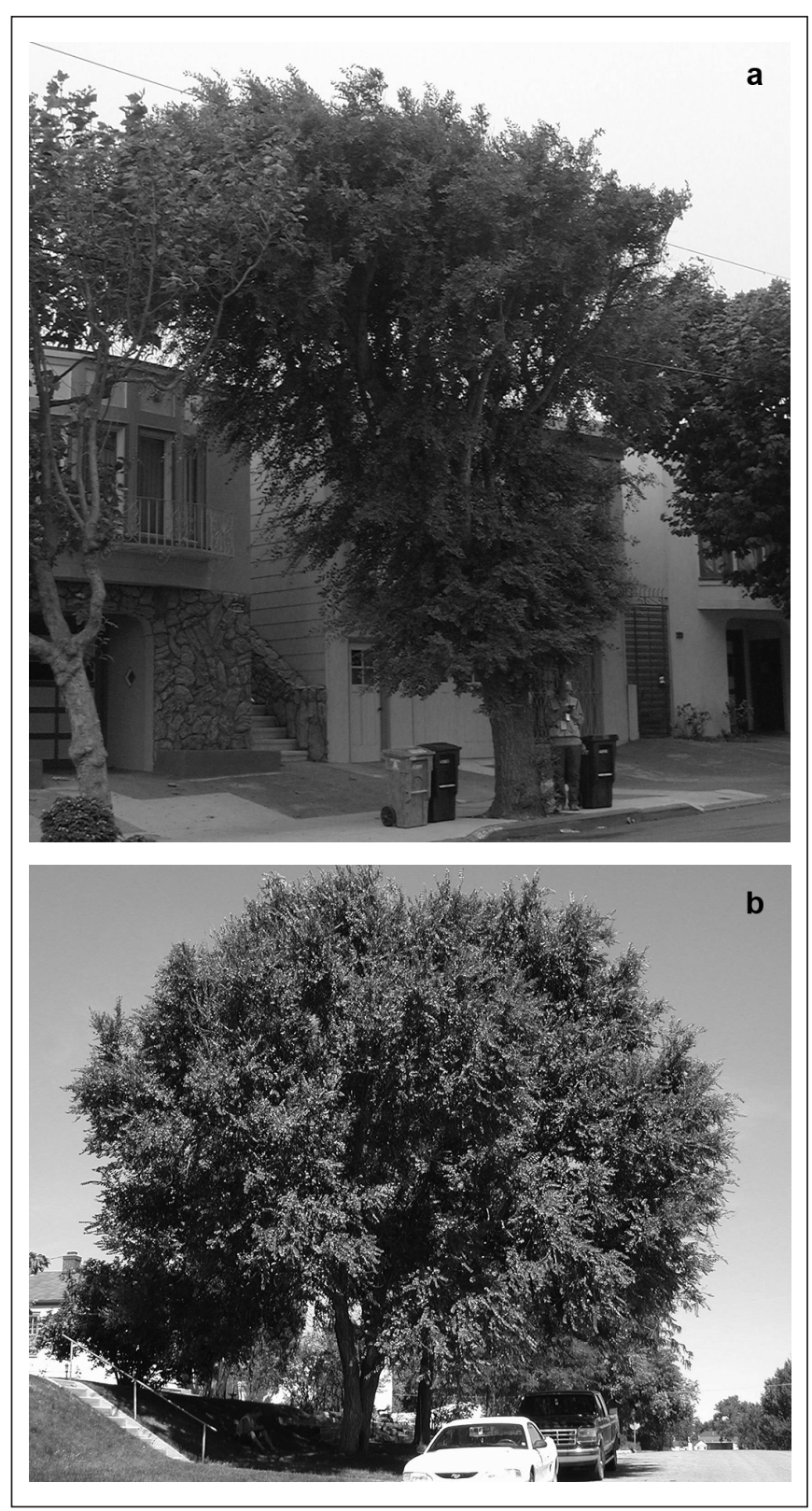

Figure 3. Siberian elms (UImus pumila) growing in San Francisco (a) and Cheyenne (b) that are 47- and 52-years-old, respectively. Space conflicts with buildings, streets, and overhead wires result in heavy pruning in San Francisco.

\section{Adjusting Tree Growth Predictions}

The comparisons presented between Fort Collins, Westminster, and Cheyenne demonstrate how differently urban trees may grow within the same major climate region. Variability can be high within the same city depending upon planting site, conditions, and management. Different growth rates result in different tree sizes and levels of ecosystem services. To better estimate the level of services provided by trees in the future, one must be able to adjust generalized size predictions to account for accelerated or stunted growth. One method for accomplishing this is illustrated by a new web-based Tree Carbon Calculator (TCC) currently in

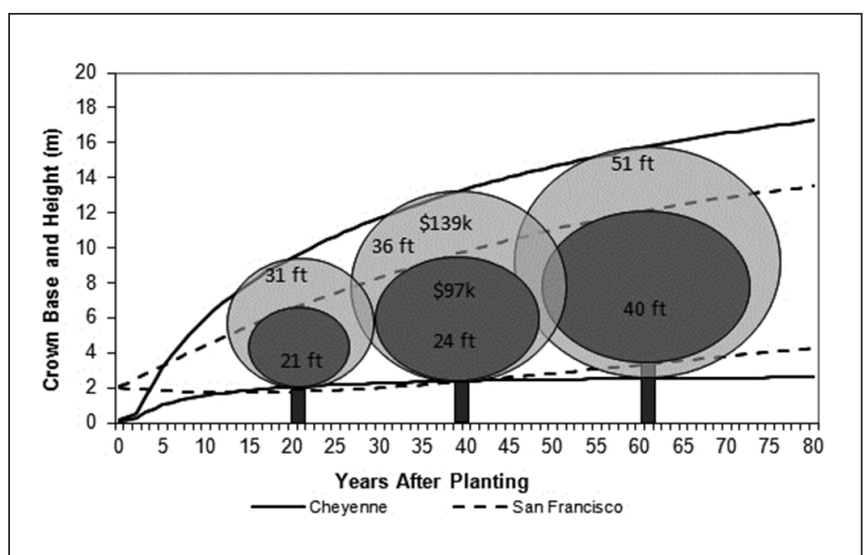

Figure 4. Benefits produced by 100 elms grown for 40 years in San Francisco are about $70 \%$ of the benefits from the same trees grown in Cheyenne. Although elms in San Francisco have a longer growing season than in Cheyenne, they are pruned more heavily.

development. With this tool, users may locate their home address on GoogleMaps ${ }^{\odot}$ and identify the trees on their parcel by outlining the tree crowns. The TCC calculates average crown diameter from the outlined crowns and uses this information to predict $\mathrm{DBH}$, height, and carbon storage sequestration with reference city tree size data derived from the growth equations database described in this paper. If users know that their trees' actual dimensions are different than those predicted, they may enter the correct dimensions, and the TCC will calculate an adjusted growth prediction curve based on the ratio of predicted and actual size (Figure 5). Imagine that a user has captured the crown of the young planetree (Platanus acerifolia) they planted five years ago in front of their home. The TCC program shows that based on crown size, the tree is $8.1 \mathrm{~m}$ tall. However, the user knows that the tree is only $6.9 \mathrm{~m}$ tall or $0.85 \%(6.9 / 8.1)$ of the original estimate. The user would then enter 6.9 into the program, which would adjust downwards future calculations by applying the 0.85 ratio to future height growth.

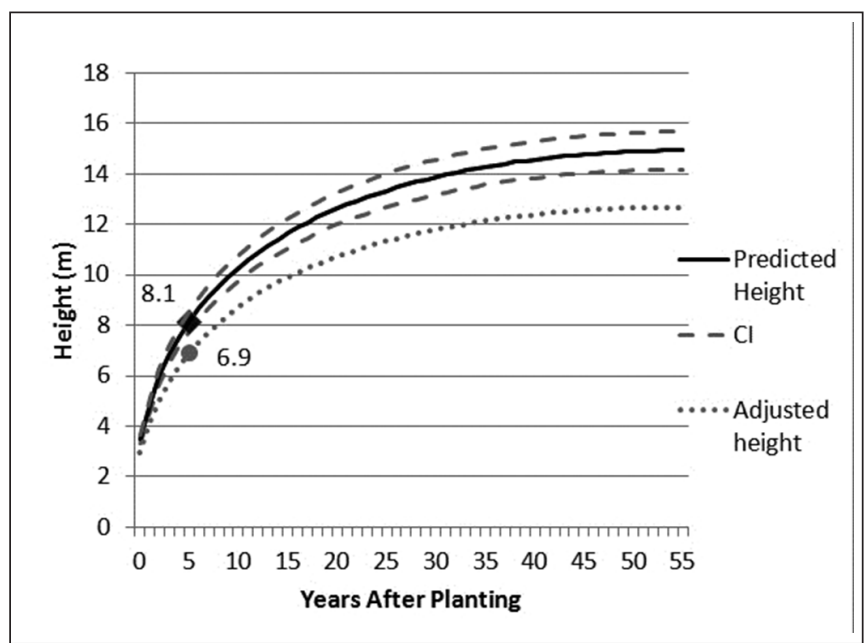

Figure 5. Height growth predictions can be adjusted in the new Tree Carbon Calculator using a ratio of user-entered size (circle) divided by the original predicted size (diamond). In this case the user entered the lower data point and the growth curve is adjusted downward by $0.85(6.9 \div 8.1)$. 


\section{CONCLUSIONS}

Regulatory policies are creating markets for services like stormwater management, carbon storage, energy conservation, and air quality improvement. As rules and reporting become more quantitative, the influence of tree selection and performance on compliance and return on investment becomes more critical. Arborists, landscape architects, and contractors will be held accountable to regulators and investors, not just for tree survival, but for long-term performance. Tree growth modeling is fundamental to quantifying the value of tree services and maximizing the health and productivity of trees. Ultimately, this science will provide the information arborists need to modify sites, select trees, and apply management practices for peak plant performance.

Long-term performance evaluation of trees is an integral component of tree modeling because it provides real-world data for calibrating models and explaining effects of site conditions and management activities on growth. Although there are several evaluation programs in the United States, they have not been integrated with tree growth modeling efforts. New long-term evaluation programs are needed that go beyond narrowly focused assessments (e.g., utility trees and elms) and encompass a variety of regional climates, growing conditions, and management regimes. Ideally, side-by-side comparisons under controlled conditions are complemented by in situ field measurements that reflect a range of landscape situations.

Modeling urban tree growth is in its infancy compared to modeling of forest and fruit trees. Empirical models, such as those found in i-Tree and L-Systems, project future tree dimensions based on growth equations derived from size measurements on large samples of trees. The USDA Forest Service reference city database contains size data from more than 17,000 trees representing 171 unique species from 16 U.S. cities. It is a valuable source of morphological data that reflects regional differences in species composition, climate, soils, site conditions, and management practices. Mining these data for correlations between tree size, condition, and other variables will increase the accuracy and robustness of tree growth models.

Process-based models translate physiological processes, such as photosynthesis and transpiration, into morphological growth. L-PEACH has successfully coupled water transport with growth and visualization, creating a promising platform for modeling urban tree growth response to pruning and future climate stressors.

Improved growth models will result in better estimates of carbon sequestration, water use, and the supply of tree biomass for future utilization. For example, green ash in Cheyenne, provided one-third the value of services compared to the same trees in nearby Fort Collins, because of dwarfed growth from climate and soil influences. Only through a broader and deeper understanding of relations between site conditions, management, and growth will urban tree modeling become more of a science and less an art. To that end, there is need for increased investment in long-term urban performance evaluation and greater collaboration among tree growth modelers from all disciplines.

\section{LITERATURE CITED}

Allen, M.T., P. Prunsinkiewicz, and T.M. DeJong. 2005. Using L-systems for modeling source-sink interactions, architecture and physiology of growing trees: The L-PEACH Model. New Phytologist 166:869-880.

Benedict, M., and E. McMahon. 2006. Green Infrastructure: Linking Landscapes and Communities. Island Press, Washington, D.C., U.S.

Brasch, S., E.G. McPherson, and L. Linsen. 2007. Visualization of timevarying tree data. pp. 129-134. In: J.J. Villanueva (Ed.). VIIP '07 The Seventh IASTED International Conference on Visualization, Imaging and Image Processing. Acta Press, Anaheim, California, U.S.

Burch, P.L., R.H. Wells, and W.N. Kline. 1996. Red maple and silver maple growth evaluated 10 years after application of paclobutrazol tree growth regulators. Journal of Arboriculture 22:61-66.

Casey Trees and Davey. 2011. National tree benefit calculator. Accessed 12/01/2011. <www.treebenefits.com/calculator>

Clark, J.R., and R. Kjelgren. 1990. Water as a limiting factor in the development of urban trees. Journal of Arboriculture 16:203-208.

Da Silva, D., R. Favreau, I. Auzmendi, and T.M. deJong. 2011. Linking water stress effects on carbon partitioning by introducing a xylem circuit into L-PEACH. Annals of Botany 108(6):1135-1145.

DeVries, R.E. 1987. A Preliminary Investigation of the Growth and Longevity of Trees in Central Park. New Brunswick, NJ: Rutgers University. M.S. thesis 95 p.

Fleming, L.E. 1988. Growth estimation of street trees in central New Jersey. New Brunswick, NJ: Rutgers University. M.S. thesis. 143 pp.

Frelich, L.E. 1992. Predicting dimensional relationships for Twin Cities shade trees. St. Paul, MN: University of Minnesota, Department of Forest Resources. 33 p.

Gerhold, H.G. 2007. Callery pear cultivars tested as street trees: Final report on a 12-year study. Arboriculture \& Urban Forestry 33:153-156.

Goodfellow, J.W., B. Blumreich, and G. Nowacki. 1987. Tree growth response to line clearance pruning. Journal of Arboriculture 13:196-200.

Grabosky, J., and E. Gilman. 2004. Measurement and prediction of tree growth reduction from tree planting space design in established parking lots. Journal of Arboriculture 30:154-164.

i-Tree Team. 2011. i-Tree. Accessed 12/01/2011. <http://itreetools.org>

Jutras, P. 2008. Modeling of Urban Tree Growth with Artificial Intelligence and Multivariate Statistics. Montreal, Quebec: McGill University. Ph.D. thesis 424 pp.

Lawrence, A.B., F.J. Escobedo, C.L. Staudhammer, and W. Zipperer. 2012. Analyzing growth and mortality in a subtropical urban forest ecosystem. Landscape and Urban Planning 104(1):85-94.

McPherson, E.G., J.R. Simpson, P.J. Peper, S.E. Maco, Q. Xiao, and P.J. Hoefer. 2003. Northern mountain and prairie community tree guide: Benefits, costs and strategic planting. U.S. Department of Agriculture, Forest Service, Pacific Southwest Research Station, Center for Urban Forest Research, Davis, California, U.S.

McPherson, G., L. Costello, J. Harding, S. Dreistadt, M.L. Flint, and S. Mezger. 2009. National elm trial: initial report from Northern California. Western Arborist 35(3):32-36.

Nielsen, C.N., O. Buhler, and P. Kristoffersen. 2007. Soil water dynamics and growth of street and park trees. Arboriculture \& Urban Forestry 33:231-245 
Nowak, D.J. 1994. Atmospheric carbon dioxide reduction by Chicago's urban forest. pp. 83-94. In: E.G. McPherson, D.J. Nowak, and R.A. Rowntree (Eds.) Chicago's urban forest ecosystem: results of the Chicago Urban Forest Climate Project. Gen. Tech. Rep. NE-186. U.S. Department of Agriculture, Forest Service, Northeastern Forest Experiment Station, Radnor, Pennsylvania, U.S.

Nowak, D.J., D.E. Crane, J.C. Stevens, R.E. Hoehn, J.T. Walton, and J. Bond. 2008. A ground-based method of assessing urban forest structure and ecosystem services. Arboriculture \& Urban Forestry 34:347-358.

Patterson, M.F., P.E. Wiseman, M.F. Winn, S. Lee, and P.A. Araman. 2011. Effects of photographic distance on tree crown attributes calculated using Urban Crowns image analysis software. Arboriculture \& Urban Forestry 37(4):173-179.

Peper, P.J., and E.G. McPherson. 2003. Evaluations of four methods for estimating leaf area of isolated trees. Urban Forestry \& Urban Greening. 2:19-29.

Peper, P.J., and E.G. McPherson. In preparation. Tree size and growth in 16 US cities. Gen. Tech. Rep. PSW-xxx. Albany, CA: U.S. Department of Agriculture, Pacific Southwest Research Station.

Peper, P.J., E.G. McPherson, and S.M. Mori. 2001a. Equations for predicting diameter, height, crown width, and leaf area of San Joaquin Valley street trees. Journal of Arboriculture 27(6):306-317.

Peper, P.J., E.G. McPherson and S.M. Mori. 2001b. Predictive equations for dimensions and leaf area of coastal Southern California street trees. Journal of Arboriculture 27(4):169-180.

Prusinkiewicz, P., and A. Lindenmayer. 1990. The Algorithmic Beauty of Plants. Springer-Verlag, New York. 228 pp.

Reineking, B., A. Huth, and C. Wissel. 2004. Generic process-based plant models for the analysis of landscape change. pp. 887-894. In: C. Pahl-Wostl, S. Schmidt, A.E. Rizzoli, and A.J. Jakeman (Eds.). Complexity and integrated resources management. Transactions of the 2nd biennial meeting of the International Environmental Modelling and Software Society. University of Osnabrück, Germany.

Rudnick, S., L. Linsen, and E.G. McPherson. 2007. Inverse modeling and animation of growing single-stemmed trees at interactive rates. pp. 217-224. In: J. Rossignac and V. Skala (Eds.). The 15th international conference in central Europe on computer graphics, visualization and computer vision 2007 (WSCG 2007). Science Press, Plzen, Czech Republic.

Sachs, R., M. Campidonica, J. Steffen, D. Hodel, and M.P. Jauniaux. 1986. Chemical control of tree growth by bark banding. Journal of Arboriculture 12:284-291.

Salas, E., L. Ene, T.G. Gregoire, E. Næsset, and T. Gobakken. 2010. Modelling tree diameter from airborne laser scanning derived variables: A comparison of spatial statistical models. Remote Sensing of Environment 114(6):1277-1285.

Seidel, D., F. Beyer, D. Hertel, S. Fleck, and C. Leuschner. 2011. 3Dlaser scanning: a non-destructive method for studying above-ground biomass and growth of juvenile trees. Agricultural and Forest Meteorology 151(10):1305-1311.

Semenzato, P., D. Cattaneo, and M. Dainese. 2011. Growth prediction for five tree species in an Italian urban forest. Urban Forestry \& Urban Greening 10(3):169-176.

Sjöman, H., and A.B. Nielsen. 2010. Selecting trees for urban paved sites in Scandinavia - A review of information on stress tolerance and its relation to requirements of tree planners. Urban Forestry \& Urban Greening 9(4):281-293.
Smith, W.B. 2002. Forest inventory and analysis: a national inventory and monitoring program. Environmental Pollution 118:8233-8242.

Smith, W.B., and S.R. Shifley. 1984. Diameter growth, survival, and volume estimates for trees in Indiana and Illinois. Res. Pap. NC-257. St. Paul, MN: U.S. Department of Agriculture, Forest Service, North Central Forest Experiment Station. 10 pp.

Soares, A.L., F.C. Rego, E.G. McPherson, J.R. Simpson, P.J. Peper, and Q. Xiao. 2011. Benefits and costs of street trees in Lisbon, Portugal. Urban Forestry \& Urban Greening 10(2):69-78.

Stoffberg, G.H., M.W. Van Rooyen, M.J. van der Linde, and H.T. Groeneveld. 2008. Predicting the growth in tree height and crown size of three street tree species in the City of Tshwane, South Africa. Urban Forestry \& Urban Greening 7(4):259-264.

Sydnor, D., J. Chatfield, D. Todd, and D. Balser. 1999. Street Tree Evaluation Project. Bulletin 877 of The Ohio State University Extension. Columbus, Ohio, U.S. 104 pp.

Torpey, J. 2007. Wyoming plant research. Horticulture: The Art and Science of Smart Gardening. Accessed 03/19/2012. < www.hortmag. com/regions/interior-west/wyomingplants>

Tzoulas, K., K. Korpela, S. Venn, V. Yli-Pelkonen, A. Kazmierczak, J. Nimela, and P. James. 2007. Promoting ecosystem and human health in urban areas using green infrastructure: a literature review. Landscape and Urban Planning 81:167-178.

Urban Forest Map. 2011. Accessed 12/01/2001. <www.urbanforestmap.org>

U.S. Department of Agriculture, Forest Service. 2008. CUFR tree carbon calculator. Accessed 12/01/2012. <http://www.fs.fed.us/ccrc/topics/ urban-forests/ctcc/>

Valentine, H.T., and A. Mäkelä. 2005. Bridging process-based and empirical approaches to modeling tree growth. Tree Physiology 25:769-779.

Wood, K. 2010. Growth rates of common tree species in Westminster, Colorado. Fort Collins: Colorado State Forest Service. 5 pp.

Young, R.F. 2010. Managing municipal green space for ecosystem services. Urban Forestry \& Urban Greening 9(4):313-322.

E. Gregory McPherson (corresponding author)

Research Forester

USDA Forest Service

Pacific Southwest Research Station

1731 Research Park Drive

Davis, CA 95618, U.S.

Paula J. Peper

Ecologist

USDA Forest Service

Pacific Southwest Research Station

1731 Research Park Drive

Davis, CA 95618, U.S. 
Résumé. La sélection, la localisation et la gestion des arbres afin de fournir des services écosystémiques deviennent de plus en plus des facettes importantes de la foresterie municipale et des services de consultation. La science de la modélisation de la croissance des arbres urbains s'avère fondamentale pour quantifier ces services. Cet article décrit trois études à long terme de croissance des arbres qui ont été menées afin d'évaluer la performance de l'arbre étant donné que la prise répétitives de données sur un même arbre permet d'engendrer des données critiques pour la calibration et la validation de modèles de croissance. Diverses approches empiriques et de processus de base pour modéliser la croissance des arbres sont revues. La modélisation dans les champs de la foresterie et de la pomologie est plus avancée que dans celui de la foresterie urbaine. La base de référence en recherches des villes du Service forestier américain (USDA Forest Service) a permis de développer plus de 1800 équations de croissance à partir de mesures prises sur plus de 17000 arbres de 16 villes. Cette base de données constitue une source d'information qui reflète les différences régionales en regard de la composition en espèces, du climat, des sols, des conditions de site et des pratiques de gestion. Plusieurs exemples illustrent comment les différences locales de climat et de pratiques de gestion peuvent influencer la croissance d'une espèce spécifique ainsi que les résultats de la valeur en services rendus. Des progrès supplémentaires dans la modélisation de la croissance des arbres en milieu urbain sont requis afin d'obtenir des aménagements paysagers plus performants en terme de design, de gestion et de modélisation.

Zusammenfassung. Die Auswahl, Lokalisierung und das Management von Bäumen als Betrag zum Ökosystem bekommt eine zunehmend wichtigere Bedeutung in der kommunalen Forstwirtschaft. Die Wissenschaft der Wachstumsanalyse urbaner Bäume ist von fundamentaler Bedeutung für die Quantifizierung dieser Leistung. Diese Studie beschreibt drei Langzeitstudien zur Bewertung von Baumwachstumsverhalten, weil wiederholte Messungen desselben Baumes wertvolle Daten zur Kalibrierung von Wachstumsmodellen und Bewertung liefern. Verschiedene empirische und prozess-basierende Ansätze zur Modulation von Baum- wachstum werden betrachtet. Die Entwicklung von Modellen ist im Bereich der Forstwirtschaft und der Pomologie viel weiter entwickelt als in der urbanen Forstwirtschaft. Die Forschung des Landwirtschaftministeriums Abt. Forst an Referenzstädten hat über 1.800 Wachstumskurven aus Messungen an mehr als 17.000 Bäumen in 16 Städten entwickelt. Die Datenbasis ist eine wertvolle Informationsquelle, die regionale Unterschiede in der Artenzusammensetzung, Klima, Böden, Standortbedingungen und Managementpraxis reflektiert. Verschiedene Beispiele illustrieren, wie Unterschiede in lokalem Klima und Managementpraxis das Wachstum einer Baumart beeinflussen können und den resultieren Einfluss des Service. Weitere Fortschritte in der Modulation von Baumwachstum werden erforderlich, um die Gestaltung und das Management von hoch funktionalen Landschaften mit Informationen zu versorgen.

Resumen. Seleccionar, ubicar y administrar árboles para proporcionar servicios en los ecosistemas se está convirtiendo en una faceta cada vez más importante del sector municipal y la consultoría forestal. La ciencia del modelado del crecimiento del árbol urbano es fundamental para cuantificar estos servicios. Este documento describe tres estudios de crecimiento del árbol a largo plazo realizados para evaluar su rendimiento. Debido a que las mediciones de los mismos árboles se repiten, se producen entonces muchos datos para la validación y calibración del modelo de crecimiento. Se revisan varios enfoques empíricos con base en el proceso para modelar el crecimiento de los árboles. El modelamiento está más avanzado en los campos de silvicultura y fruticultura que en la silvicultura urbana. La investigación en la ciudad de referencia del Servicio Forestal USDA ha desarrollado más de 1,800 ecuaciones de crecimiento en más de 17,000 árboles en 16 ciudades. La base de datos es una valiosa fuente de información que refleja las diferencias regionales en la composición de especies, clima, suelos, condiciones del sitio y prácticas de gestión. Varios ejemplos ilustran cómo las diferencias en clima local y prácticas de gestión pueden influir en el crecimiento de una especie única y el valor resultante de los servicios. Los avances en el modelado del crecimiento del árbol urbano son necesarios para informar sobre el diseño, gestión y modelado de paisajes de alto rendimiento. 